\title{
The Qing Policy of Self-Isolation in China
}

\author{
Elvina Al'bertovna Khusnutdinova ${ }^{1}$, Dmitry Evgenyevich Martynov $^{1} \&$ Yulia Aleksandrovna Martynova ${ }^{1}$ \\ ${ }^{1}$ Kazan Federal University, Russia \\ Correspondence: Dmitry Evgenyevich Martynov, Kazan Federal University, Russia. E-mail: \\ dmitrymartynov80@mail.ru
}

Received: June 9, 2019

Accepted: August 25, 2019 Online Published: August 31, 2019

doi:10.5539/jpl.v12n5p11

URL: https://doi.org/10.5539/jpl.v12n5p11

\begin{abstract}
This article discusses the difficult period of the XVII - XIX century in China's development. As a result of Manchu taking over China, the Qing empire was formed, and historiographers differ in evaluating the results of its rule. On the one hand, the Qing dynasty inherited the sinocentric view of the world from its predecessors - China was declared as the center of the universe, and all other states as sidelined vassals, who should not be subject to equal treatment. Manchu attempted to apply this doctrine in practice, which resulted in a significant expansion of the state, the annexation of Mongolia, Tibet and Xinjiang, and border wars with Russia, Vietnam and Burma. The self-isolation policy led to economic stagnation while the population was growing strongly. These problems could not have been resolved within the bounds of the traditional society.
\end{abstract}

Keywords: history, China, Qing self-isolation policy, involution

\section{Introduction}

The Qing empire inherited from its predecessors the superiority over all neighbouring countries and peoples. Gifts brought by foreign ambassadors were treated as tribute from vassal rulers. Military action of neighboring peoples were declared a "barbarian uprising" that requires "quelling". The ruling dynasty in Peking tried to make their population believe in an exaggerated view of its power; that also created a pretext for continued takeovers of land from foreign countries.

The Qing army was moved to the Amur Region which was already occupied by Russia, and imposed the Nerchinsk Treaty of 1689 on Russia, under which the left bank of the Amur River was handed over to China, while the territory between the Stanovoy Mountains and Amur became undemarcated. This territory was only returned to Russia in 1858.

The Qing dynasty made multiple invasions into Burma and Vietnam to force these states to recognize the supremacy of China. In late XVII century, Northern Mongolia submitted to the Qing dynasty and was cruelly exploited by it. In the middle of the XVIII century, The Qing army attacked the lands of the Djungarian state in Western Mongolia, and killed around one million people. Only some of them managed to escape to Russia. All peoples of other countries and some peoples from the Qing Empire were treated as "barbarians" who need to be kept in submission.

Despite a noticeable economic growth, by the end of the XVIII century Qing emperors began facing stagnation and crises. The primary reason was the Qing's conquests. Continued military expeditions and the need to maintain order in the occupied territories required a large amount of money and higher taxes. To obtain funds for military campaigns, Manchu had to increase taxes on the population, which angered peasants; corruption increased; land was scarce due to population growth; excessive growth of lending took place, which was required for agriculture; criminal gangs; poorly thought-through state policy towards merchants and artisans. Instead of supporting these groups of people, the Manchu, just like the preceding dynasties, treated merchants as people who are not beneficial to the throne; Manchu noblemen's influence at the royal court grew; people were keen to get rid of foreign emperors; Western countries actively sought to break the self-isolation of China; there were active sects promoting the fight against the government.

The first serious clash of the Qing with the people occurred in 1796, when the White Lotus Society led an uprising. The fight with the rebels lasted for 8 years. Despite the government's victory, Chinese people were prepared to continue the struggle against Manchu. The entire XIX century, the country was engulfed in uprisings of a scale not seen before and the Taiping Revolution. 


\section{Methods}

This research is based on the general scientific principles:

- historism, which as part of the system approach permits use of the source method, historical-genetic method, historical comparison method, chronological method and culturological method of research;

- systemacity, which allows looking at the phenomenon of a single sociocultural space and rebuilding elements of the political and legal system when reconstructing it if the historical data is insufficient.

This work also uses the historical genetic method.

\section{Results}

By the end of the XVIII century, the Qing state (i.e. the Manchurian state) entered a crisis period due to the overpopulation of the country and scarcity of land, and due to the increasing corruption among bureaucrats. The population of the country grew steadily. By the end of the XVIII century, around 300 million people lived in the Empire. Agricultural land was scarce, land prices increased, as did rent. All of that caused an increase in people without land and workers. People who were deprived of money organized into gangs and robbed others.

One of the causes of the crisis was the military campaigns of the Qing Empire in the XVIII century. Each required money from the budget, and the conquered lands needed to be supported. The new, expanded borders of the state needed to be protected, too. In the context of that crisis, the popularity of secret societies and religious sects increased.

Secret societies opposed the poverty of the lower-income people and often prepared for anti-government uprisings. One of the main goals of the secret societies and sects was to overthrow the Manchu dynasty and restore a Chinese ruler on the throne.

Mystical rituals played a large role in these societies. One of them was the understanding of martial arts. Members believed that those skills made them invincible against weapons.

By the end of the XVIII century, a sect called White Lotus stood out as popular among peasants and urban poor people, as well as among officials who wanted to restore a Chinese dynasty at the throne. In late XVIII century, different provinces had branches of the White Lotus. These branches can also be divided into several sects. Thus, by the start of the 1796-1804 rebellion, China had a large number of sects that followed this teaching.

In 1795, minority Miao people started an uprising. Peasants were also taken away from farms to build new roads and irrigation systems. But the most difficult burden for peasants was the conquest by the Qing empire. In 1755-1758, a war with Djungaria took place, and Djungaria was annexed by Manchu in 1758 In 1756, Burma claimed independence from China. All of these wars expanded the territory of China, but the costs of the military campaigns were borne by the peasants, with taxes being increased again.

Various sects and secret societies suffered a number of defeats in early XIX century, but that did not mean they would stop trying to overthrow the Manchu dynasty. The peasant war of the White Lotus was only the first societal shock for the Qing dynasty in the XIX century. These societies would be active during the entire XIX century, which would ultimately lead to the start of a dynasty crisis, which the Manchu would not survive.

Starting from 1649, Chinese people were unable to trade outside of the Qing Empire, i.e. in foreign countries. Building large ships that may sail far away from the land in the open seas was punishable by death. In 1716, the trade of copper and zinc with foreigners was prohibited, as was the trade of iron in 1733. From 1759, the export of silk ceased. The export of silk was repeatedly banned several times in later years. Even goods permitted for export were restricted in many ways: the annual amount of tea leaves and rhubarb for export was limited.

Imports were sharply restricted too. Particularly, the import of European books was banned. Economic relations with neighboring countries were strongly restricted. The Qing government created barriers for the expansion of business between Russian and Chinese merchants, and ceased all trade in China multiple times, including in 1762 for 6 years, and in 1785 for 7 years.

The trade with Korea, which was already very restricted, was also strictly controlled, especially the exchange of goods across the border. Trade between Japan and China was under double pressure from the Qing and from the Tokugawa shogunate. Having declared itself a "closed" country, Japan has practically ceased trade with China by the end of the XVIII century. In 1757, Emperor Hongli banned foreign trade in all sea ports except Guangzhou, where Europeans were not even allowed to settle within the city limits. They were banned from learning the Chinese language. Those who taught it to the "overseas devils" were executed. Chinese people were not allowed to 
move to islands close to the shore to use the arable land there. Violators had to return to the mainland, while their houses were burned down.

In 1787, inhabiting islands near Zhejiang province was subject to a separate ban. An invisible, but strong "Wall of China" was created along the Chinese coast, with the only door in it being Guangzhou. This has completed the process of "closing" the Qing Empire. The isolation policy has reached its limit.

The isolation was not economically motivated, and contradicted the needs for the historical development of China, increasing its technical, economic and cultural gap from the West. The defense capability of the state was weakening too, although that became apparent only in the middle of the XIX century, when the country was rocked by trade or "opium" wars with England and France.

\section{Discussion}

Contemporary sociocultural research of processes in the Far East before the Modern era often base on economic research. Leading contemporary authors underscore the fact that even in the best years of China's history of foreign policy, that policy remained vulnerable and guided by external factors. These features can be traced all the way up till now. Research of "proto-globalization", the so-called Manila Transpacific Trade System, note that one of the reasons for the self-isolation of China during the Qing was the activity of Dutch merchants and their takeover of Taiwan. European merchants allied with anti-Qing rebels, further worsening the situation. Clifford Girtz, a well-known researcher, introduced the term "involution" to denote the development of Asian traditional societies, which F. Huang adapted to describe the development of the Qing society. These approaches are widely used in contemporary science. With that said, when interpreting the results of research, the culture may determine the position of the parties and the possible integration or clash.

\section{Summary}

The Manchu did not have the political experience required for managing such a large state. The Chinese people were more developed and progressive than the Manchu. They had an established administrative system and skilled bureaucracy.

The Qing Empire inherited from the dynasties of the great states that earlier ruled China a demand for superiority over all other states and peoples, especially those bordering China.

In 1757, an imperial order started the policy of self-isolation of China from others, especially Western European countries. All foreign trade was subject to the control of the Qing authorities and only occured through Canton (Guangzhou).

China's self-isolation policy contributed to the preservation of reactionary feudal practices and damaged its economic, social and cultural development.

By maintaining a reactionary policy, and by rejecting the achievements of other nations in science and technology, feudal rulers reinforced the country's gap with other states, and weakened China. This weakness was exploited by British and other colonizers.

\section{Conclusions}

For the first two hundred years, the policy of self-isolation of China was yielding positive results. A country protected from external contacts with foreign states developed an independent character. The large army was maintained for the purposes of conquests. The first country to suffer from the Chinese expansion was Korea. Korea's fate was soon shared by Outer Mongolia, where local dukes recognized the supremacy of Chinese emperors. In 1760, a new province called Xinjiang ("new border") was created by the Manchu Qing dynasty. It comprised the Djungarian khanate and the Eastern Turkestan. By late XVIII century, Tibet also joined the Manchu-Chinese state. The conquering army was stopped when it was defeated in wars against Burma in 1769 and Vietnam in 1789. The expansion of the Qing Empire to the north-east and north led to wars with the Russian Empire. During these two centuries, the country doubled in size. Nevertheless, China remained only a part of the powerful Qing empire. Qing rulers treated even official representatives of foreign states as vassals.

\section{Acknowledgements}

The work is performed according to the Russian Government Program of Competitive Growth of Kazan Federal University.

\section{References}

Christopher, M. I. (2007). State, Peasant, and Merchant in Qing Manchuria, 1644-1862. Stanford University Press. 
Dai, Y. C. (2019). The White Lotus War: Rebellion and Suppression in Late Imperial China. Seatlle: University of Washington Press.

Dittmar, S., \& Ning, C. (Eds.). (2016). Managing Frontiers in Qing China: The Lifanyuan and Libu Revisited. Leiden: Brill.

Ferdinand, P. (2016). Westward ho - the China dream and "One Belt, One Road". Chinese foreign policy under Xi Jinping. International Affairs, 92(4), 941-957. https://doi.org/10.1111/1468-2346.12660

Glushkova, S., Lomakina, O., \& Sakulyeva, T. (2019) The economy of developing countries in the context of globalization: Global supply chain management. International Journal of Supply Chain Management, 8(1), 876-884.

Gunn, G. (2016). World Trade Systems of the East and West: Nagasaki and the Asian Bullion Trade Networks. Leiden: Brill. https://doi.org/10.1163/9789004358560_003

Hao, P. (2019). Trade Relations between Qing China and Tokugawa Japan: 1685-1859. Springer-Singapore.

Margalit, Y. (2013). Explaining Social Policy Preferences: Evidence from the Great Recession. American Political Science Review, 107(1), 80-103. https://doi.org/10.1017/S0003055412000603

Muhametzyanov, R. R. (2014). The East and the West: From holism to dialogue through confrontation. Terra Sebus.

Sasaki, T. (2011). Nature and Human Communities. Tokyo: Springer-Japan.

Seiwert, H. M. (2003). Popular Religious Movements and Heterodox Sects in Chinese History. Leiden: Brill.

Shi, Z. H. (2017). Agricultural Development in Qing China: A Quantitative Study, 1661-1911. Leiden: Brill.

Sutton, D. S. (2003). Ethnic revolt in the Qing empire: the 'Miao uprising' of 1795-97 reexamined. Asia Major, third series, 16(2), 105-152.

Zhou, F. Z. (2018). Institutional Change and Rural Industrialization in China: The Putting-Out System in Handicraft Industry in Late Qing and Early Republic Period. Singapore: World Scientific Publishing. https://doi.org/10.1142/8993

\section{Copyrights}

Copyright for this article is retained by the author(s), with first publication rights granted to the journal.

This is an open-access article distributed under the terms and conditions of the Creative Commons Attribution license (http://creativecommons.org/licenses/by/4.0/). 